\title{
Improved Method of Analysing Mortality Statistics
}

\author{
Minoru Uematsu, M. D. \\ Department of Hygiene and Public Health, School of Medicine, Irwata \\ Medical University (Prof. M. Uematsu)

\section{死亡統計解析の新しい方法}

岩手医科大学医学部衛生学公管衛生学教室

植松稔

\section{Abstract}

The angular transformation

$$
\theta=\operatorname{Arcsin} \sqrt{\mathrm{P}}
$$

transforms a probability $\mathrm{p}$ varying from 0 to 1 into an angle varying from 0 to $\pi / 2$ radians and is remarkable in that the amount of information concerning $\theta$ is constant.

$\operatorname{Arcsin} \sqrt{\mathrm{P}}$ may be written

$$
\operatorname{Arcsin} \sqrt{ } \overline{\mathrm{P}}=\sqrt{\mathrm{P}}+\frac{1}{2} \frac{\mathrm{p}}{3} \sqrt{\mathrm{P}}+\frac{1 \cdot 3}{2 \cdot 4} \frac{\mathrm{p}^{2}}{5} \sqrt{\mathrm{P}}+\cdots \cdots+\frac{1 \cdot 3 \cdots \cdots(2 \mathrm{n}-1)}{2 \cdot 4 \cdots \cdots \cdots \cdots 2 \mathrm{n}} \frac{\mathrm{p}^{\mathrm{n}}}{2 \mathrm{n}+1} \sqrt{\mathrm{P}}+\cdots
$$

[Taylor expantion of $f(x)$ about $x=p$ ]

If a probability $\mathrm{p}$ were as small as a death rate, the second term $\mathrm{p}^{2 / 3} / 2 \cdot 3$ and the following terms $3 \mathrm{p}^{2 / 5} / 2 \cdot 4 \cdot 5+\cdots \cdots$ would be negligible altogether. Thus, normal deviate for the mortality of any sample community and its standard error Et are calculated respectively as follows :

$$
\mathrm{t}=\frac{2 \Sigma\left[\mathrm{N}_{\mathrm{A}}\left(\sqrt{\mathrm{P}_{\mathrm{A}}}-\sqrt{\mathrm{P}_{\mathrm{a}}}\right)\right]}{\Sigma \mathrm{N}_{\mathrm{A}}} \text {, and } \mathrm{Et}=\frac{1}{\sqrt{\Sigma \mathrm{N}_{\mathrm{A}}}}
$$

$\mathrm{P}$ : age specific death rate for age $\mathrm{A}$ among sample community.

$\mathrm{Pa}$ : age specific death rate for the same age among the standard population.

$\mathrm{N}$ : the number of persons A years old among sample community.

Normal deviate for the mortality of 46 prefectures has been investigated using vital statistics of Japan of 1960: these values were further comparatively studied with the crude or corrected death rates respectively. Naturally, correlation between normal deviate for the mortality and corrected death rate was far higher than that between normal deviate and crude death rate both in male and female populations.

It has been deducted by the author that normal deviate for mortality is a useful indicator for evaluating levels of health of communities. 
[抄録] 訂正死亡率や 0 才平均余命は，いずれも年令別死亡率から導かれる。これら解析方法 そみられる共通の欠陥は, 比率の変動の情報量としての重みが無視されていることである. 著者 は，既往の諸方法に代わるべき一新法を考案した。

率 $\mathrm{P}$ を逆正弦変換し，かつこれを Taylor 展開して第 2 項以下を省略すると

$$
\begin{aligned}
\theta= & \operatorname{Arcsin} \sqrt{\mathrm{P}}=\sqrt{\mathrm{P}}+\frac{1}{2} \frac{\mathrm{p}}{3} \sqrt{ } \overline{\mathrm{P}}+\frac{1 \cdot 3}{2 \cdot 4} \frac{\mathrm{p}^{2}}{5} \sqrt{\mathrm{P}}+\cdots \cdots \\
& \cdots \cdots+\frac{1 \cdot 3 \cdots \cdots(2 \mathrm{n}-1)}{2 \cdot 4 \cdots \cdots \cdots \cdot 2 \mathrm{n}}-\frac{\mathrm{Pn}}{2 \mathrm{n}+1} \sqrt{\mathrm{P}}+\cdots \cdots \cdots \cdot \sqrt{\mathrm{P}}
\end{aligned}
$$

標準集団に括ける年令別死亡率を $\mathrm{Pa}$ ，標本集団に括ける年令別死亡率および人口をそれぞれ $\mathrm{P}_{\mathrm{A}}$ 拉よび $\mathrm{N}_{\mathrm{A}}$ とする，後者が前者の任意標本である場合には

$$
\mathrm{t}=\frac{2 \Sigma\left[\mathrm{N}_{\mathrm{A}}\left(\sqrt{ } \overline{\mathrm{P}}_{\mathrm{A}}-\sqrt{\mathrm{P}} \mathrm{a}\right)\right]}{\Sigma \mathrm{N}_{\mathrm{A}}}
$$

は平均 0 ，標準偏差 $1 / \sqrt{\Sigma \mathrm{N}_{\mathrm{A}}}$ なる正規分布をする.よつて，この式によつて算出された て，地域の死亡正規偏差とすることができる.

男女別に，昭和35年全国人口を標準集団として，46 都道府県について死亡正規偏差を算出し， これを粗死亡率执よび訂正死亡率と比較検討し，もつて，死亡正規偏差が地域の健康水準を表わ すのに有用な示標であることを示した。

The amount of information of observed rate is related not only to the sample size but also to the value of the rate itself ${ }^{1,2)}$. Nevertheless, in computing adjusted death rates, adjustment is made only for the age distribution of the population, the disparity of the invariance of rate according to its value being given no consideration ${ }^{3,4)}$.

The author has worked out a way to obviate the above-mentioned defect of the corrected death rates.

\section{The Computing of Normal Deviate}

The angular transformation

$$
\theta=\operatorname{Arcsin} \sqrt{\mathrm{p}}
$$

transforms a probability $\mathrm{p}$ varying from 0 to 1 into an angle varying from 0 to $\pi / 2$ radians, and is remarkable in that the amount of information concerning $\theta$ is constant.

$\operatorname{Arcsin} \sqrt{\mathrm{P}}$ may be written

$\operatorname{Arcsin} \sqrt{\bar{P}}=\sqrt{ } \overline{\mathrm{P}}+\frac{1}{2} \frac{\mathrm{p}}{3} \sqrt{\mathrm{P}}+\frac{1 \cdot 3}{2 \cdot 4} \frac{\mathrm{p}^{2}}{5} \sqrt{\mathrm{P}}$

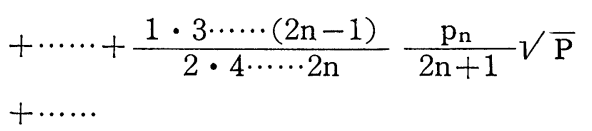

〔Taylor-series expansion of $f(x)$ about $\mathrm{x}=\mathrm{p}$ ]

If a probability $\mathrm{p}$ were as small as a death rate, the second term $\mathrm{p}^{3 / 2} / 2 \cdot 3$ and the following terms $3 p^{5 / 2} / 2 \cdot 4 \cdot 5+\cdots \cdots$ would be negligible altogether. Thus, normal deviate $t$ for the mortality of any sample community and its standard error Et are calculated respectively as follows:

$$
\begin{aligned}
\mathrm{t}=\frac{2 \Sigma\left[\mathrm{Na}\left(\sqrt{\mathrm{P}_{\mathrm{A}}}-\sqrt{\mathrm{Pa}}\right]\right.}{\Sigma \mathrm{N}_{\mathrm{A}}}, \\
\text { and } \mathrm{E} \mathrm{t}=\frac{1}{\sqrt{\Sigma \mathrm{N}_{\mathrm{A}}}} .
\end{aligned}
$$

$\mathrm{P}_{\mathrm{A}}$ : age specific death rate for age $\mathrm{A}$ among sample community.

$\mathrm{Pa}$ : age specific death rate for the same age among the standard population.

$\mathrm{N}_{\mathrm{A}}$ : the number of persons $\mathrm{A}$ years old among sample community. 
Table 1. Normal Deviate Computation for a Sample Community Female, Iwata Prefecture, 1960

\begin{tabular}{|c|c|c|c|c|c|}
\hline $\begin{array}{l}(1) \\
\text { Age }\end{array}$ & $\begin{array}{c}(2) \\
\text { Population } \\
\mathrm{N}_{\mathrm{A}}\end{array}$ & $\begin{array}{c}(3) \\
\text { Death Rate } \\
\text { PA }\end{array}$ & $\begin{aligned} &(4) \\
& \text { Death Rate for } \\
& \text { Studard Population } \\
& \text { Pa }\end{aligned}$ & $\begin{array}{l}(5) \\
\sqrt{\mathrm{PA}_{\mathrm{A}}}\end{array}$ & $\begin{array}{l}(6) \\
\sqrt{\mathrm{Pa}}\end{array}$ \\
\hline Total & 742400 & & & & \\
\hline $0-4$ & 75400 & 0.010000 & 0.007399 & 0.10000 & 0.08602 \\
\hline $5-9$ & 85300 & 0.000914 & 0.000757 & 0.03023 & 0.02751 \\
\hline $10-14$ & 85000 & 0.000529 & 0.000423 & 0.02300 & 0.02827 \\
\hline $15-19$ & 62500 & 0.000976 & 0.000799 & 0.03124 & 0.02827 \\
\hline $20-24$ & 61400 & 0.001596 & 0.001362 & 0.03995 & 0.03691 \\
\hline $25-29$ & 64000 & 0.001688 & 0.001546 & 0.04109 & 0.03932 \\
\hline $30-34$ & 61000 & 0.001902 & 0.001807 & 0.04361 & 0.04251 \\
\hline $35-39$ & 48600 & 0.002305 & 0.002250 & 0.04801 & 0.04743 \\
\hline $40-44$ & 41200 & 0.003471 & 0.002961 & 0.05892 & 0.05442 \\
\hline $45-49$ & 35700 & 0.005014 & 0.004492 & 0.07081 & 0.06702 \\
\hline $50-54$ & 34400 & 0.006192 & 0.006673 & 0.07869 & 0.08169 \\
\hline $55-59$ & 27500 & 0.010327 & 0.009907 & 0.10162 & 0.09953 \\
\hline $60-64$ & 20300 & 0.021133 & 0.015825 & 0.14537 & 0.12580 \\
\hline $65-69$ & 16700 & 0.029401 & 0.026706 & 0.17147 & 0.16342 \\
\hline $70-74$ & 12500 & 0.052400 & 0.046520 & 0.22891 & 0.21568 \\
\hline $75-79$ & 6800 & 0.112353 & 0.082208 & 0.33519 & 0.28672 \\
\hline $80 \&$ over & 4100 & 0.216341 & 0.154651 & 0.46512 & 0.39326 \\
\hline \multicolumn{6}{|c|}{$\Sigma\left(\mathrm{NA}_{\mathrm{A}} \sqrt{\mathrm{PA}}\right)=47421.43100$} \\
\hline \multicolumn{6}{|c|}{$\Sigma\left(\mathrm{N}_{\mathrm{A}} \sqrt{ } \overline{\mathrm{Pa}}\right)=43751.64300$} \\
\hline \multicolumn{6}{|c|}{ Normal Deviate for the Prefecture $=\frac{(47421.431-43751.643) \times 2}{742400}=+0.00989$} \\
\hline
\end{tabular}

An example of normal deviate computations is shown in Table 1.

\section{Materials and Results}

The study was based on the vital statistics in Japan in 1960 and the report of one percent sampling survey of census in the same year. Total male or female population was regarded as a standard population.

Table 2 and 3 give normal deviate for mortality of male and female respectively in 46 prefectures. The tables show also crude and corrected death rates, being referred to the report from the Division of
Health and Welfare Statistics. ${ }^{5)}$

\section{Discussion}

1. Assuming that $\mathrm{Pa}$ and $\mathrm{P}_{\mathrm{A}}$ are age specific death rate for age $\mathrm{A}$ respectively among standard population and among its random sample, and that $\mathrm{N}_{\mathrm{A}}$ is the number of persons A years old among sample community, the distribution of $\operatorname{Arcsin} \sqrt{\mathrm{P}_{\mathrm{A}}}$ would be a normal distribution with a mean $\operatorname{Arcsin} \sqrt{\mathrm{P}_{\mathrm{A}}}$ and variance $1 /\left(4 \mathrm{~N}_{\mathrm{A}}\right)$. Then,

$$
\begin{aligned}
& 2 \mathrm{~N}_{\mathrm{A}}\left(\operatorname{Arcsin} \sqrt{\mathrm{PA}_{\mathrm{A}}}-\operatorname{Arcsin} \sqrt{\mathrm{Pa}}\right) \\
& \quad \fallingdotseq 2 \mathrm{~N}_{\mathrm{A}}\left(\sqrt{\mathrm{P}_{\mathrm{A}}}-\sqrt{\mathrm{Pa}}\right)
\end{aligned}
$$

would have a standardized normal distribu- 
Table 2. Crude Death Rates, Corrected Death Rates and Normal Deviate for Mortality; For Individual Prefectures

Male, 1960

\begin{tabular}{|c|c|c|c|c|c|c|c|c|c|}
\hline \multirow{2}{*}{ No. } & \multirow{2}{*}{ Prefecture } & \multicolumn{2}{|c|}{ Population } & \multicolumn{2}{|c|}{$\begin{array}{c}\text { Crude } \\
\text { Death Rate }\end{array}$} & \multicolumn{2}{|c|}{$\begin{array}{c}\text { Correted } \\
\text { Death Rate }\end{array}$} & \multicolumn{2}{|c|}{$\begin{array}{l}\text { Normal Deviate } \\
\text { for Mortality }\end{array}$} \\
\hline & & Number & Proportion & per 1000 & Ranking & per 1000 & Ranking & Value & Ranking \\
\hline & All Japan & 45819500 & 1000 & 8.23 & & 8.23 & & 0 & \\
\hline 1 & Hokkaido & 2561500 & 56 & 6.98 & 4 & 8.13 & 16 & +0.0009 & 24 \\
\hline 2 & Aomori & 683800 & 15 & 8.45 & 11 & 10.09 & 45 & +0.0134 & 46 \\
\hline 3 & Iwate & 703700 & 15 & 8.78 & 17 & 8.80 & 36 & +0.0069 & 42 \\
\hline 4 & Miyagi & 835500 & 18 & 7.87 & 6 & 8.88 & 38 & -0.0003 & 20 \\
\hline 5 & Akita & 658400 & 14 & 8.92 & 19 & 10.63 & 46 & +0.0088 & 45 \\
\hline 6 & Yamagata & 633200 & 14 & 9.35 & 31 & 9.20 & 44 & +0.0050 & 39 \\
\hline 7 & Fukushima & 986000 & 22 & 9.13 & 24 & 9.02 & 43 & +0.0063 & 40 \\
\hline 8 & Ibaraki & 1004900 & 22 & 9.24 & 26 & 8.46 & 28 & +0.0010 & 25 \\
\hline 9 & Tochigi & 733400 & 16 & 9.14 & 25 & 8.97 & 41 & +0.0039 & 36 \\
\hline 10 & Gunma & 768100 & 17 & 8.90 & 18 & 8.91 & 39 & +0.0006 & 22 \\
\hline 11 & Saitama & 1190400 & 26 & 8.54 & 13 & 8.79 & 35 & +0.0030 & 33 \\
\hline 12 & Chiba & 1132900 & 25 & 9.00 & 21 & 8.34 & 27 & +0.0001 & 21 \\
\hline 13 & Tokyo & 4967100 & 108 & 5.59 & 1 & 7.65 & 4 & -0.0106 & 1 \\
\hline 14 & Kanagawa & 1727800 & 38 & 6.51 & 2 & 8.15 & 18 & -0.0039 & 9 \\
\hline 15 & Niigata & 1170800 & 26 & 8.68 & 15 & 8.23 & 23 & -0.0026 & 11 \\
\hline 16 & Toyama & 492800 & 11 & 9.10 & 22 & 8.75 & 34 & +0.0039 & 37 \\
\hline 17 & Ishikawa & 465800 & 10 & 9.59 & 37 & 8.66 & 31 & +0.0016 & 30 \\
\hline 18 & Fukui & 362200 & 8 & 9.58 & 36 & 8.17 & 19 & -0.0040 & 8 \\
\hline 19 & Yamanashi & 382000 & 8 & 8.97 & 20 & 7.69 & 6 & -0.0044 & 7 \\
\hline 20 & Nagano & 956500 & 21 & 9.26 & 27 & 7.84 & 8 & -0.0082 & 3 \\
\hline 21 & Gifu & 790700 & 17 & 8.70 & 16 & 7.67 & 5 & -0.0067 & 5 \\
\hline 22 & Sizuoka & 1379400 & 30 & 7.97 & 7 & 7.73 & 7 & +0.0017 & 31 \\
\hline 23 & Aichi & 2075700 & 45 & 7.39 & 5 & 7.59 & 2 & -0.0066 & 6 \\
\hline 24 & Mie & 712600 & 16 & 9.37 & 32 & 8.04 & 15 & -0.0036 & 10 \\
\hline 25 & Shiga & 403100 & 9 & 9.81 & 39 & 8.32 & 26 & -0.0008 & 16 \\
\hline 26 & Kyoto & 970200 & 21 & 8.12 & 9 & 7.60 & 3 & -0.0081 & 4 \\
\hline 27 & Osaka & 2756700 & 60 & 6.97 & 3 & 8.67 & 32 & -0.0003 & 19 \\
\hline 28 & Hyogo & 1912000 & 42 & 8.22 & 10 & 8.19 & 21 & -0.0005 & 17 \\
\hline 29 & Nara & 381600 & 8 & 9.60 & 38 & 8.97 & 42 & +0.0014 & 28 \\
\hline 30 & Wakayama & 483400 & 11 & 9.38 & 33 & 7.94 & 10 & -0.0017 & 12 \\
\hline 31 & Tottori & 288800 & 6 & 9.82 & 41 & 8.04 & 14 & -0.0015 & 14 \\
\hline 32 & Shimane & 430400 & 9 & 10.37 & 46 & 7.93 & 9 & -0.0015 & 13 \\
\hline 33 & Okayama & 819000 & 18 & 9.81 & 40 & 7.47 & 1 & -0.0086 & 2 \\
\hline 34 & Hiroshima & 1052200 & 23 & 9.34 & 29 & 8.15 & 17 & +0.0010 & 26 \\
\hline 35 & Yamaguchi & 780200 & 17 & 9.41 & 34 & 8.22 & 22 & +0.0038 & 35 \\
\hline 36 & Tokushima & 402200 & 9 & 10.15 & 44 & 8.67 & 33 & +0.0016 & 29 \\
\hline 37 & Kagawa & 434900 & 9 & 9.92 & 42 & 8.01 & 13 & -0.0004 & 18 \\
\hline 38 & Ehime & 714500 & 16 & 9.52 & 35 & 7.94 & 11 & +0.0012 & 27 \\
\hline 39 & Kochi & 414600 & 9 & 10.34 & 45 & 8.24 & 24 & -0.0014 & 15 \\
\hline 40 & Fukuoka & 1933600 & 42 & 8.01 & 8 & 8.49 & 29 & +0.0049 & 38 \\
\hline 41 & Saga & 448300 & 10 & 9.27 & 28 & 8.87 & 37 & +0.0071 & 44 \\
\hline 42 & Nagasaki & 860300 & 19 & 8.65 & 14 & 8.54 & 30 & +0.0064 & 41 \\
\hline 43 & Kumamoto & 884800 & 19 & 9.34 & 30 & 8.19 & 20 & +0.0033 & 34 \\
\hline 44 & Oita & 586200 & 13 & 9.98 & 43 & 8.94 & 40 & +0.0071 & 43 \\
\hline 45 & Miyazaki & 552500 & 12 & 8.49 & 12 & 8.27 & 25 & +0.0008 & 23 \\
\hline 46 & Kagoshima & 934800 & 20 & 9.11 & 23 & 7.97 & 12 & +0.0028 & 32 \\
\hline
\end{tabular}

tion with mean 0 and variance $1 /(4 \mathrm{Na})$. Then, normal deviate $\mathrm{t}$ for the mortality of a random sample community is calculated as follows :

$$
\mathrm{t}=\frac{2 \Sigma\left[\mathrm{N}_{\mathrm{A}}\left(\sqrt{\mathrm{P}_{\mathrm{A}}}-\sqrt{\mathrm{Pa}}\right)\right]}{\Sigma \mathrm{N}_{\mathrm{A}}}
$$

The distribution of $\mathrm{t}$ obtained here is a normal distribution with mean 0 and variance $1 / \Sigma \mathrm{N}_{\mathrm{A}}$.

Thus, normal deviate $\mathrm{t}$ for the mortality of any sample community expressed in the 
Table 3. Crude Death Rates, Corrected Death Rates and Normal Deviate for Mortality; For Individual Prefectures

Female, 1960

\begin{tabular}{|c|c|c|c|c|c|c|c|c|c|}
\hline \multirow{2}{*}{ No. } & \multirow{2}{*}{ Prefecture } & \multicolumn{2}{|c|}{ Population } & \multicolumn{2}{|c|}{$\begin{array}{c}\text { Crude } \\
\text { Death Rate }\end{array}$} & \multicolumn{2}{|c|}{$\begin{array}{c}\text { Correted } \\
\text { Death Rate }\end{array}$} & \multicolumn{2}{|c|}{$\begin{array}{c}\text { Normal Deviate } \\
\text { for Mortality }\end{array}$} \\
\hline & & Number & Proportion & per 1000 & Ranking & per 1000 & Ranking & Value & Ranking \\
\hline & All Japan & 47527700 & 1000 & 6.92 & & 6.92 & & 0 & \\
\hline 1 & Hokkaido & 2493000 & 52 & 5.51 & 3 & 6.94 & 16 & +0.0008 & 28 \\
\hline 2 & Aomori & 728100 & 15 & 6.66 & 10 & 7.55 & 41 & +0.0059 & 40 \\
\hline 3 & Iwate & 742400 & 16 & 7.26 & 15 & 8.58 & 46 & +0.0099 & 46 \\
\hline 4 & Miyagi & 889800 & 19 & 6.29 & 5 & 7.01 & 23 & -0.0028 & 7 \\
\hline 5 & Akita & 696700 & 15 & 6.66 & 9 & 7.58 & 43 & +0.0051 & 38 \\
\hline 6 & Yamagata & 704900 & 15 & 7.37 & 16 & 7.39 & 38 & -0.0009 & 18 \\
\hline 7 & Fukushima & 1057700 & 22 & 7.55 & 20 & 7.90 & 45 & +0.0065 & 42 \\
\hline 8 & Ibaraki & 1048100 & 22 & 8.09 & 32 & 7.12 & 30 & +0.0015 & 31 \\
\hline 9 & Tochigi & 787700 & 17 & 7.45 & 18 & 7.00 & 22 & +0.0028 & 35 \\
\hline 10 & Gunma & 820500 & 17 & 7.41 & 17 & 7.04 & 25 & +0.0002 & 26 \\
\hline 11 & Saitama & 1250700 & 26 & 7.19 & 13 & 6.87 & 13 & +0.0017 & 32 \\
\hline 12 & Chiba & 1182400 & 25 & 7.69 & 25 & 7.03 & 24 & +0.0000 & 24 \\
\hline 13 & Tokyo & 4658600 & 99 & 4.73 & 1 & 6.34 & 2 & -0.0087 & 1 \\
\hline 14 & Kanagawa & 1688300 & 36 & 5.42 & 2 & 6.62 & 7 & -0.0061 & 2 \\
\hline 15 & Niigata & 1270900 & 27 & 7.56 & 21 & 6.98 & 20 & -0.0017 & 12 \\
\hline 16 & Toyama & 522500 & 11 & 7.81 & 27 & 7.42 & 39 & +0.0012 & 30 \\
\hline 17 & Ishikawa & 511500 & 11 & 8.34 & 40 & 7.00 & 21 & +0.0004 & 27 \\
\hline 18 & Fukui & 390400 & 8 & 8.37 & 41 & 7.21 & 33 & -0.0026 & 9 \\
\hline 19 & Yamanashi & 408300 & 9 & 7.67 & 24 & 6.52 & 5 & -0.0012 & 14 \\
\hline 20 & Nagano & 1020500 & 21 & 8.14 & 35 & 7. 12 & 29 & -0.0030 & 6 \\
\hline 21 & Gifu & 853900 & 18 & 7.23 & 37 & 6.94 & 18 & -0.0003 & 22 \\
\hline 22 & Sizuoka & 1403100 & 30 & 6.52 & 8 & 6.40 & 3 & -0.0043 & 4 \\
\hline 23 & Aichi & 2143100 & 45 & 6.34 & 6 & 7.16 & 31 & -0.0027 & 8 \\
\hline 24 & Mie & 761100 & 16 & 8.16 & 36 & 6.94 & 17 & +0.0002 & 25 \\
\hline 25 & Shiga & 446200 & 9 & 8.96 & 45 & 7.11 & 27 & -0.0005 & 21 \\
\hline 26 & Kyoto & 1020800 & 21 & 7.22 & 14 & 6.67 & 9 & -0.0048 & 3 \\
\hline 27 & Osaka & 2739600 & 58 & 5.84 & 4 & 6.87 & 14 & -0.0006 & 20 \\
\hline 28 & Hyogo & 1995500 & 42 & 6.83 & 11 & 6.61 & 6 & -0.0011 & 15 \\
\hline 29 & Nara & 410100 & 9 & 8.24 & 38 & 7.57 & 42 & +0.0031 & 36 \\
\hline 30 & Wakayama & 520500 & 11 & 8.03 & 31 & 6.65 & 8 & -0.0015 & 13 \\
\hline 31 & Tottori & 310300 & 7 & 8.51 & 42 & 7.19 & 32 & -0.0009 & 17 \\
\hline 32 & Shimane & 459600 & 10 & 8.66 & 43 & 6.89 & 15 & -0.0007 & 19 \\
\hline 33 & Okayama & 868400 & 18 & 8.13 & 33 & 6.77 & 10 & -0.0019 & 10 \\
\hline 34 & Hiroshima & 1124900 & 24 & 7.73 & 26 & 6.80 & 11 & -0.0010 & 16 \\
\hline 35 & Yamaguchi & 822900 & 17 & 7.64 & 22 & 7.28 & 35 & -0.0001 & 23 \\
\hline 36 & Tokushima & 437900 & 9 & 8.69 & 44 & 7.36 & 36 & +0.0062 & 41 \\
\hline 37 & Kagawa & 484800 & 10 & 7.99 & 30 & 6.48 & 4 & -0.0036 & 5 \\
\hline 38 & Ehime & 780400 & 16 & 7.64 & 23 & 6.34 & 1 & -0.0020 & 11 \\
\hline 39 & Kochi & 447400 & 9 & 9.03 & 46 & 7.26 & 34 & +0.0018 & 33 \\
\hline 40 & Fukuoka & 2033800 & 43 & 6.40 & 7 & 6.95 & 19 & +0.0011 & 29 \\
\hline 41 & Saga & 493800 & 10 & 7.90 & 28 & 7.65 & 44 & +0.0084 & 45 \\
\hline 42 & Nagasaki & 887600 & 19 & 7.51 & 19 & 7.54 & 40 & +0.0082 & 44 \\
\hline 43 & Kumamoto & 967600 & 20 & 7.98 & 29 & 7.11 & 28 & +0.0055 & 39 \\
\hline 44 & Oita & 640000 & 13 & 8.28 & 39 & 7.37 & 37 & +0.0073 & 43 \\
\hline 45 & Miyazaki & 582100 & 12 & 7.02 & 12 & 6.83 & 12 & +0.0020 & 34 \\
\hline 46 & Kagoshima & 1019300 & 21 & 8.13 & 34 & 7.08 & 26 & +0.0049 & 37 \\
\hline
\end{tabular}

above-mentioned equation could be used as an indicator of the mortality.

This indicator $\mathrm{t}$ has standard error $1 / \sqrt{\overline{\Sigma \mathrm{NA}}}$.

The indicator which the author reported earlier ${ }^{6,7)}$ was the devided value of $t$ by its standard error $1 / \sqrt{\overline{\Sigma \mathrm{N}_{\mathrm{A}}}}$. The author, from now on, uses $t$ in the sense indicated in the present paper.

2. Normal deviate for the mortality of 46 prefectures has been studied further comparatively with the crude or corrected death 

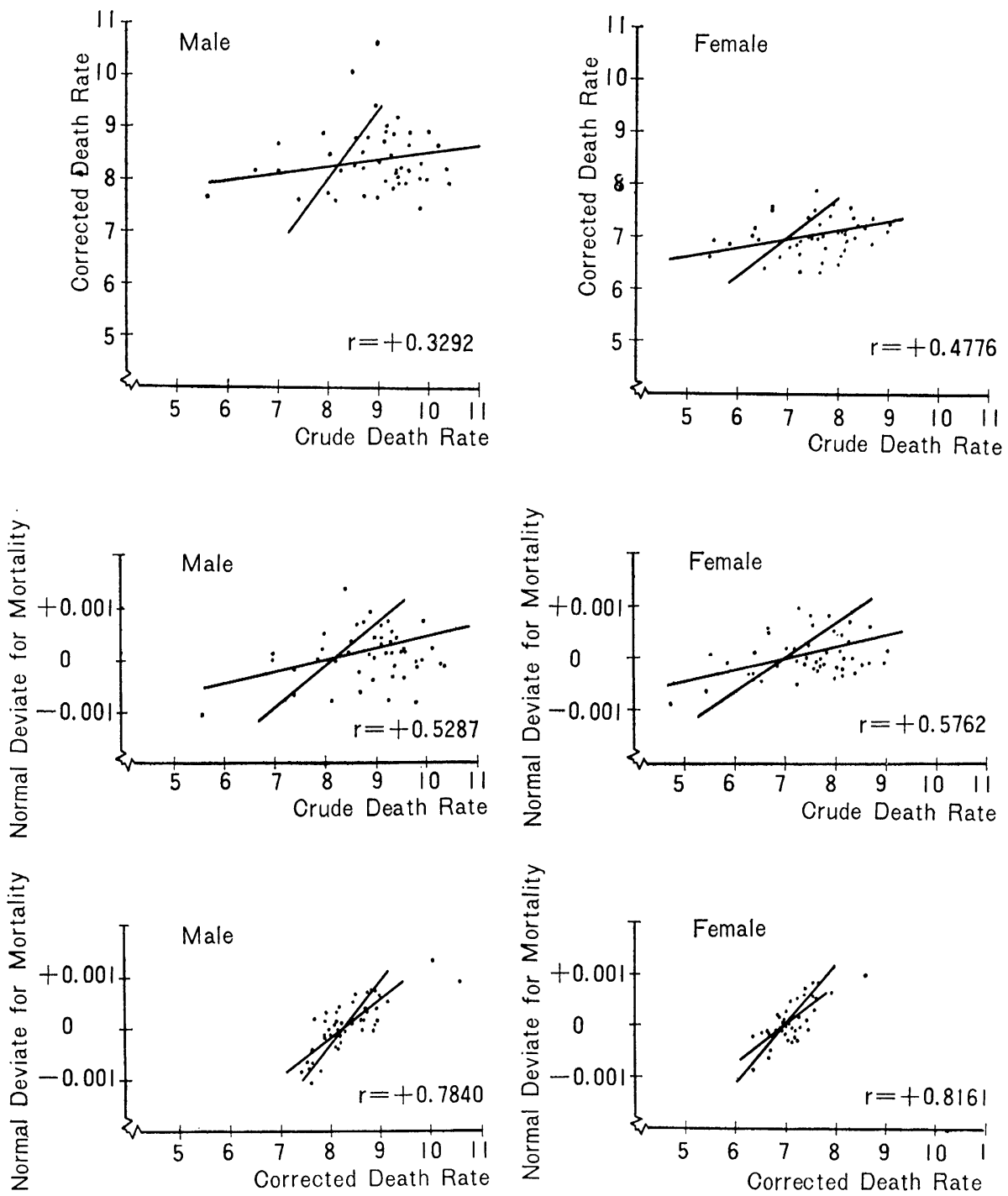

Fig. Correlation between two indicators

Upper left: between death rate and corrected death rate in male.

Upper right: the same as the above in female.

Center left: between crude death rate and normal deviate for mortality in male.

Center right: the same as the above in female.

Lower left: corrected death rate and normal deviate for mortality in male.

Lower right: the same as the above in female.

rates respectively. (Fig.)

In computing correlation coefficient between two indicators, a weight was attached to each indicator in proportion to the popu- lation of the prefecture. Naturally, correlation between normal deviate for the mortality and corrected death rate was far higher than that between normal deviate and 
crude death rate both in male and female populations.

Although, corrected death rate was more closely related to normal deviate for mortality than to crude death rate, correlation coefficient between normal deviate for mortality and corrected death rate was just only +0.7840 in the male and +0.8161 in the female. In other words, common factors influence both corrected death rate and normal deviate for mortality in the ratio of 0.8 to total factors, and uncommon factors influence separately each indicator in the ratio of $\sqrt{1-0.8^{2}}=0.6$.

This difference between two indicators is mainly due to whether the disparity of the invariance of rates according to its value is taken into account or not.

In computing corrected death rate, adjustment is made only for the age distribution of the population, the disparity of the invariance of rates according to its value being given no consideration. For example, excess number of deaths 10 in the case of expected number of deaths 100 is equally treated as the excess deaths 10 in the case of expected number of deaths 10 . This computation does not seem to be reasonable from the standpoint of the theory of information.

3. The comparion of certain cause-specific corrected death rate of some two populations is made usually for elucidating which population is more affected by the cause of the disease. In this epidemiological survey, normal deviate anyalysis would be considered to be more effective than the method using corrected death rate.

4. Normal deviate for the mortality is based on the structure of observed sample population which is not always similar to the structure of standard population. In addition, though standard error of the corrected death rate is almost impossible to calculate, that of normal deviate for obseved mortality is very easily obtained. From this point of view, normal deviate for mortality has advantage over corrected death rate.

\section{Summary and Conclusion}

Improved method has been worked out to obviate the defect of the corrected death rates.

Applying angular transformation

$$
\begin{aligned}
& \theta=\operatorname{Arcsin} \sqrt{\mathrm{P}}=\sqrt{\mathrm{P}}+\frac{1}{2} \frac{\mathrm{P}}{3} \sqrt{\mathrm{P}} \\
& +\frac{1 \cdot 3 \mathrm{P}^{2}}{2 \cdot 4 \cdot 5} \sqrt{\mathrm{P}}+\cdots \cdots \\
& +\frac{1 \cdot 3 \cdots(2 \mathrm{n}-1) \quad \mathrm{Pn}^{\mathrm{n}}}{2 \cdot 4 \cdots 2 \mathrm{n}} \sqrt{\mathrm{P}}+\cdots \cdots \fallingdotseq \sqrt{\mathrm{P}}
\end{aligned}
$$

normal deviate $\mathrm{t}$ for the mortality of any sample community and its standard error Et are respectively caluculated as follows:

$$
\begin{aligned}
\mathrm{t}=\frac{2 \Sigma\left[\mathrm{N}_{\mathrm{A}}\left(\sqrt{\mathrm{PA}_{\mathrm{A}}}-\sqrt{\mathrm{Pa}}\right)\right]}{\Sigma \mathrm{N}_{\mathrm{A}},} \\
\text { and } \mathrm{Et}=\frac{1}{\sqrt{\Sigma \overline{\mathrm{N}_{\mathrm{A}}}}}
\end{aligned}
$$

$\mathrm{P}_{\mathrm{A}}$ : age specific death rate for age $\mathrm{A}$ among sample community.

$\mathrm{Pa}$ : age specific death rate for the same age among the standard population.

$\mathrm{N}_{\mathrm{A}}$ : the number of persons $\mathrm{A}$ years old among sample community.

It has been deducted by the author that normal deviate for mortality is a useful indicator for evaluating levels of health of communities.

\section{References}

1. Fisher, R. A. and F. Yates: Statistical Tables for Biological, Agricultural and Medi- 
cal Research, 6th ed., Oliver and Boyd, London (1963)

2. Yerushalmy. J.: A mortality index for use in place of the age adjusted death rate, Amer. J. Publ. Health, 41 : 907-922 (1951)

3. Cox, P. R. : Demography, 3rd ed., pp.120143, Camblidge Univ. Press, London and New York (1959)

4. Swaroop, S. : Introduction to Health Statistics pp. 182-185, Livingston, Edinburgh and London (1960)

5. (Division of Health and Welfare Statistics): (Corrected Death Rates for Several
Leading Causes in Japan, 1960), pp. 26-28, (Ministry of Public Health and Welfare), Tokyo (1963)

6. Uematsu, M. : Normal deviate analysis of mortality statistics (Japanese with English abstract), Minzoku Eisei (Human Ecology and Race Hygiene), 30: 74-79 (1964)

7. Uematsu, M.: An improved method of normal deviate analysis of mortality statistics (Japanese with English abstract), Minzoku Eisei (Human Ecology and Race Hygiene), 31 : 1 -5 (1965) 